SHEs: Conference Series 3 (2) (2020) 77 - 85

\title{
The Value of Indonesian Unity Learning in The Historical Education Study Progtam of Galuh University
}

\author{
Terra Erlina \\ Universitas Galuh \\ terraerlina77@gmail.com
}

\section{Article History}

accepted 1/09/2020

approved 4/10/2020

published 1/12/2020

\begin{abstract}
This study aims to determine the inculcation of nationalism values and the difficulties experienced by lecturers, and to find out the values contained in point three of Pancasila. This study uses a qualitative method. Data were collected through observation, in-depth interviews, and documentation. The results showed the process of planting the values of nationalism and the difficulties faced by the lecturers History in the process of instilling the values of nationalism is due to the backgrounds of students with different characters and a lack of understanding of the meaning of nationalism itself. As well as the values contained in the third principle of the Indonesian Unity, namely the values of nationalism, love of the country, willing to sacrifice, cutting and steadfast, responsible and trustworthy.
\end{abstract}

Keywords: Nationalism values, history learning

\begin{abstract}
Abstrak
Penelitian ini bertujuan untuk mengetahui penanaman nilai-nilai nasionalisme serta kesulitan-kesulitan yang dialami oleh dosen, dan untuk mengetahui nilai-nilai yang terkandung dalam pancasila poin tiga. Penelitian ini menggunakan metode kualitatif. Data dikumpulkan melalui observasi, wawancara mendalam, dan dokumentasi. Hasil penelitian menunjukkan proses penanaman nilai-nilai nasionalisme serta kesulitan-kesulitan yang dihadapi oleh dosen Sejarah dalam proses penanaman nilai-nilai nasionalisme dikarenakan latar belakang mahasiswa yang berbeda-beda karakter serta kurangnya pemahaman arti nasionalisme itu sendiri. Serta nilai-nilai yang terkandung dalam sila ketiga Persatuan Indonesia yaitu Nilai Nasionalisme, cinta tanah air, rela berkorban, menotong dan tabah, bertanggungjawab dan dapat dipercaya.
\end{abstract}

Kata Kunci: Nilai-nilai, nasionalisme, pembelajaran sejarah

Social, Humanities, and Education Studies (SHEs): Conference Series p-ISSN 2620-9284 https://jurnal.uns.ac.id/shes e-ISSN 2620-9292 


\section{PENDAHULUAN}

Kehidupan bermasyarakat sejak sebelum Pancasila sebagai dasar Negara dirumuskan dalam satu sistem nilai. Nilai adalah yang dapat diambil dari Sila Kedua Pancasila, yaitu Percaya kepada Tuhan dan toleransi, gotong royong, musyawarah, solidaritas dan setia kawanan social, maka dapat diambil dari makna bersifat universal. Sila kedua merupakan Perlindungan Negara, terhadap segenap bangsa Indonesia dan seluruh tumpah darah Indonesia dengan tujuan untuk memajukan kesejahteraan umum, mencerdaskan kehidupan bangsa, dan ikut melaksanakan ketertiban dunia yang berdasarkan Kemerdekaan, Perdamaian Abadi dan Keadilan Sosial serta Negara mengatasi segala paham golongan dan segala paham perseorangan, serta pengakuan Negara terhadap Kebhineka-tunggal Ikaan dan bangsa Indonesia dalam kehidupannya.

Hakikat sila-sila Pancasila Nampak pada susunan sila-sila Pancasila yang bersifat organis. Pancasila merupakan satu kesatuan yang majemuk tunggal karena setiap sila tidak bisa berdiri sendiri. Adapun Hyrarkis dan Piramydal Pancasil, adalah ciri Pancasila yang saling berurutan 5 (lima) sila yang menunjukan suatu tingkatan dalam luasnya dan isi sifatnya yang merupakan pengkhususan dari sila-sila dimukanya sehingga dapat dikatakan 5(lima) sila saling berkaitan. Dari salah satu nilai praksis silasila Pancasila adalah merupakan realisasi nilai-nilai instrumental suatu pengalaman sehari-hari, maka dari 5 (lima) sila yang terdiri dari salah satu kita ambil dari nilai-nilai praksis sila ke dua Pancasila adalah seperti diatas tadi bahwa nilai praksis Pancasila dapat terwujud dan dilaksanakan dalam kehidupan sehari-hari oleh seluruh warga negaranya.

Hal tersebut diatas harus dapat diwujudkan apabila setiap warga Negara menunjukan sikap positif dalam kehidupan sehari-hari, adapun sikap positif tersebut diantaranya sikap yang ditunjukan yang berkaitan dengan hak-hak asasi manusia diantaranya:

1. Menempatkan persatuan, kesatuan, kepentingan dan keselamatan bangsa dan Negara diatas kepentingan pribadi dan golongan.

2. Rela berkorban untuk kepentingan bangsa dan Negara.

3. Cinta tanah air dan bangsa.

4. Bangga sebagai bangsa Indonesia dan ber Tanah Air Indonesia.

5. Menunjukan pergaulan demi persatuan dan kesatuan bangsa yang ber-Bhineka Tunggal lka (Kemendikbud,

Sesuai dengan uraian di atas maka tujuan peneliti ini yang pertama mengetahui nilai Kemanusiaan Yang Adil Dan Beradab, Sila ke dua dari Pancasila. Dan yang kedua yaitu implementasi nilai kedua dari Pancasila pada pembelajaran di program studi pendidikan sejarah.

\section{Landasan Teori}

\section{A. Pengertian Nilai}

Nilai atau "Value" (bahasa Inggris) termasuk bidang kajian filsafat. Persoalanpersoalan tentang nilai dibahas dan dipelajari salah satu cabang filsafat yaitu Filsafat Nilai (axiology, Theory of Value). Filsafat sering juga diartikan sebagai ilmu tentang nilai-nilai. Istilah nilai di dalam bidang filsafat dipakai untuk menunjuk kata benda abstrak yang artinya"keberhargaan" (Worth) atau 'kebaikan' (googness), dan kata kerja yang artinya suatu tindakan kejiwaan tertentu dalam menilai atau melakukan penilaian Franke (Kaelan, 229)

Di dalam Dictionary of Sosciology and Related Sciences dikemukakan bahwa nilai adalah kemampuan yang dipercayai yang ada pada suatu benda untuk memuaskan manusia. Sifat dari suatu benda yang menyebabkan narik minat seseorang atau kelompok, (the believed capacity of any object to statisfy a human desire). Jadi nilai itu pada hakikatnya adalah sifat atau kualitas yang melekat pada suatu objek, bukan 
objek itu sendiri. Sesuatu itu mengandung nilai artinya ada sifat atau kualitas yang melekat pada sesuatu itu. Misalnya, bunga itu indah, perbuatan itu susila. Indah, susila adalah sifat atau kualitas yang melekat pada bunga dan perbuatan. Dengan demikian maka nilai itu sebenarnya adalah suatu kenyataan yang "tersembunyi" di balik kenyataan kenyataan lainnya. Ada nilai itu karena adanya kenyataankenyataan lain sebagai pembawa nilai (wartrager) (Kaelan, $2014: 80$ )

Max Scheler mengemukakan bahwa nilai-nilai yang ada, tidak sama luhurnya dan sama tingginya. Nilai-nilai itu secara senyatanya ada yang lebih tinggi dan ada yang lebih rendah dibandingkan dengan nilai-nilai lainnya. Menurut tinggi rendahnya, nilai-nilai dapat dikelompokkan dalam empat tingkatan:

1. Nilai-nilai kenikmatan: dalam tingkatan ini terdapat deretan nilai-nilai yang mengenakkan dan tidak menggenakan (die wertreihe des Angenehmen und Unangehmen), yang menyebabkan orang senang atau menderita tidak enak.

2. Nilai-nilai kehidupan: dalam tingkat ini terdapatlah nilai-nilai yang penting bagi kehidupan (werte des vztalen Fuhlens) misalnya kesehatan, kesegaran jasmani, kesejahteraan umum.

3. Nilai-nila kejiwaan: dalam tingkat ini terdapat nilai-nilai kejiwaan (geistige werte) yang sama sekali tidak tergantung dari keadaan jasmani maupun lingkungan. Nllainilai semacam ini ialah keindahaan, kebenaraan, dan pengetahuan murni yang dicapai dalam filsafat.

4. Nilai-nilai kerohanian: dalam tingkat ini terdapatlah modalitas nilai dari yang suci dan tak suci (wermodalitat des Heiligenung Unheilegeri). Nilai-nilai semacam ini terutama dari nilai-nilai pribadi.

Walter G. Everet menggolong-golongkan nilai-nilai manusiawi ke dalam delapan kelompok yaitu:

1. Nilai-nilai ekonomis (ditujukan oleh harga pasar dan meliputi semua benda yang dapat dibeli).

2. Nilai-nilai kejasmanian (membantu pada kesehatan, efisiensi dan keindahan dari kehidupan badan).

3. Nilai-nilai hiburan (nilai-nilai permainan dan waktu senggang yang dapat menyumbangkan pada pengayaan kehidupan).

4. Nilai-nilai social (berasal mula dari keutuhan kepribadiaan dan social yang diingkinkan).

5. Nilai-nilai watak (keseluruhan dari keutuhan kepribadian dan social yang diinginkan).

6. Nilai-nilai estetis (nilai-nilai keindahaan dalam alam dan karya seni).

7. Nilai-nilai intelektual (nilai-nilai pengetahuaan dan pengajaraan kebenaraan)

8. Nilai-nilai keagamaan.

Notonagoro membagi nilai menjadi tiga macam, yaitu:

1. Nilai material, yaitu segala sesuatu yangn berguna bagi kehidupan manusia, atau kebutuhan material ragawi manusia.

2. Nilai Vital, yaitu segala sesuatu yang berguna bagi manusia, untuk dapat mengadakan kegiatan atau aktivitas.

3. Nilai kerohanian, yaitu segala sesuatu yang berguna bagi rohani manusia nilai kerohanian ini dapat dibedakan atas empat macam:

a. Nilai kebenaraan, yang bersumber pada akal(ratio, budi, cipta) manusia.

b. Nilai keindahaan atau nilai estetis, yang bersumber pada unsur perasaan (esthetis, goevel, rasa) manusia.

c. Nilai kebaikan atau nilai moral, yang bersumber pada unsur kehendak (will, Wolen, karsa) manusia.

d. Nilai religius, yang merupakan nilai kerohanian tertinggi dan mutlak. Nilai religius ini bersumber kepada kepercayaanj atau keyakinan manusia. (Kaelan, 2014: 81-82)

\section{B. Pembelajaran Sejarah}


Pembelajaran sejarah yang baik adalah pembelajaran yang mampu menumbuhkan kemampuan siswa melakukan konstruksi masa sekarang dengan mengaitkan atau melihat masa masa lalu yang menjadi basis topic pembelajaraan sejarah. Kemampuan melakukan konstruksi ini harus ditemukan secara kuat agar pembelajaran tidak terjerumus dalam pembelajaraan yang bersifat konservatif. Kontekstualitas sejarah harus kuat mengemuka dan berbasis pada pengalaman pribadi para siswa. Apalagi sejarah tidak akan terlepas dari konsep waktu., kontinyuitas dan perubahan.

Mengutip pendapat Fernand Braudel (Lechte, 2001) memahami sejarah ada tiga kerangka waktu, event history (short term/jangka pendek), conjucture (mid term/jangka menengah) dan longue duree (long term/jangka panjang). Sejarah pada satu tempat dan komunitas terkait dengan ketiga konsep waktu tersebu. Selain itu dari sudut ruang, Braudel menambahkan satu lagi, yaitu ekonomi dunia di mana ini merupakan urut analisis makro terkait dengan perkembangan pertukaran barang dan jasa, jika dikaitkan dengan waktu kalender, event history berlangsung antara beberapa minggu, musim sampai beberapa tahun. Conjungture berlangsung sekitar 10-50 tahun sedangkan lengue duree berlangsung lebih lama bias sampai beberapa abad (Y. R. Subakti 2010).

\section{Kemanusiaan yang Adil dan Beradab}

Nilai kemanusiaan yang adil dan beradab, mengandung makna kesadaran sikap dan perilaku yang sesuai dengan nilai moral dalam hidup bersama atas tuntutan mutlak hati nurani dengan memperlakukan sesuatu hal sebagaimana mestinya.

Yang perlu diperhatikan dan merupakan dasar hubungan semua umat manusiadalam mewujudkan nilai kemanusiaan yang adil dan beradab adalah pengakuan hak asasi manusia. Manusia harus diakui dan diperlakukan sesuaivdengan harkat dan martabatnya sebagai Tuhan Yang Maha Esa yang sama derajatnya. Untuk itu perlu dikembangkan juga sikap saling mencintai sesame manusia, sikap tenggang rasa. Oleh karena itu sikap dan prilaku semena-mena terhadap orang lain merupakan perbuatan yang tidak sejalan dengan nilai kemanusiaan yang adil dan beradab.

Dalam sila ke dua terkandung nilai-nilai humanistis, antara lain:

1 Pengakuan atas adanya martabat manusia dengan segala hak asasinya yang harus dihormati oleh siapa pun.

2 Perlakuan yang adil terhadap sesame manusia.

3 Pengertian manusia beradab yang memiliki daya cipta, rasa, karsa dan iman, sehingga nyatalah bedanya dengan mahluk lain.

\section{METODE}

Penelitian kualitatif adalah penelitian yang bermaksud untuk memahami fenomena tentang apa yang dialami oleh subjek penelitian misalnya perilakunya., persepsi, motivasi, tindakan dan lain-lain secara holostik dan dengan cara deskripsi dalam bentuk kata-kata dan bahasa, pada suatu konteks khusus yang alamiah dan dengan memanfaatkan berbagai metode alamiah. Metode penelitian kualitatif adalah metode yang berdasarkan pada filsafat postpositivisme, sedangkan untuk meneliti pada objek alamiah, dimana penelti adalah sebagai instrument kunci, teknik pengumpulan data dilakukan dengan cara triangulasi (gabungan). Analisis data bersifat induktif atau kualitatif, dan hasil penelitian lebih menekankan makna daripada generalisasi (Sugiyono, 2013) 


\section{A. Nilai Kemanusiaan Yang Adil dan Beradab}

Nilai ke dua dari Pancasila Kemanusiaan yang Adil dan Beradab yaitu, nilai azas kemanusian pada Pancasila dikembangkan oleh rantai emas. Apabila dilihat lebih dalam lagi, rantai emas pada perisai memiliki mata rantai yang berbeda. Terdapat bentuk persegi dan lingkaran yang melambangkan pria dan wanita sebagai rakyat Indonesia. Rantai-rantai tersebut terikat tanpa putus yang menunjukan akan hubungan rakyat Indonesiayang saling terikat dan saling membantu . Baik pria dan wanita memiliki kesetaraan hak sebagai rakyat Indonesia.

Sila kedua berbunyi Kemanusiaan Yang Adil Dan Beradab memiliki nilai-nilai yang terkandung sebagai berikut :

1. Semua rakyat Indonesia memiliki hak yang sama di mata hulum, agama, masyarakat dan lainnya.

2. Tidak ada perbedaan antara ras satu dengan yang lainnya antar sesame rakyat Indonesia.

3. Sikap menghormati antar umat beragama

4. Tidak memaksakan kehendak antar umat beragama.

5. Tidak mencemooh atau mengejek kepercayaan orang lain (https://saintif.com/com/nilai-nilai).

Artinya bahwa kita dituntut untuk bias mengembangkan kepribadian, dan bisa menguasai kemampuan berpikir, bersikap rasional, dan dinamis, serta berpandangan luas sebagai manusia intelektual demi kelangsungan berkehidupan bangsa dan negaranya, dengan mengedepankan kepentingan pribadi bangsa dan negaranya.

Penanaman dan penguatan kesadaran nasional tentang hal tersebut sangat penting karena apabila kesadaran tersebut tidak segera dilaksanakan dan disosialisasikan di Internasionalisasikan dan diperkuat implementasikannya, maka masalah yang lebih besar akan segera melanda bangsa ini.Betapa pentingnya Pancasila sebagai dasar dan idiologi Negara ini, untuk ditanamkan dan menanamkan nilai-nilai moral Pancasila kepada generasi penerus cita-cita bangsa, yang diharapkan dapat memperkokoh modalitas peran serta, membangun negeri tercinta ini.

Kesadaran gaya hidup yang sederhana, cinta produk dalam negeri, pentingnya semangat kesatuan dan persatuan hidup generasi mendatang, solidaritas nasional, norma-norma dalam pergaulan, kesehatan mental bangsa, penegakan hukum, dan kesadaran terhadap ideologi Pancasila, dengan demikian maka sila ke dua Pancasila adalah merupakan kehendak Negara, bukan kehendak perseorangan atau golongan demi terwujudnya tujuan Negara, yang harus kita sadari bersama. Misalnya:

1. Agar memiliki kemampuan untuk menggambil sikap bertanggung jawab sesuai hati nuraninya.

2. Agar memiliki kemampuan untuk mengenali masalah hidup dan kesejahteraan serta cara-cara pemecahaannya.

3. Agar mampu mengenali perubahan-perubahan dan perkembangan ilmu pengetahuan teknologi dan seni.

4. Agar mampu memaknai peristiwa sejarah dan nilai-nilai budaya bangsa untuk menggalang persatuan Indonesia (Kemendikbud: 25).

Cinta Tanah Air dan Bangsa, adalah merupakan sarana atau wadah yang dapat mempersatukan bangsa Indonesia, untuk dapat mencintai tanah airnya dan bangsanya sendiri. Yaitu, memelihara kerukunan, kebersamaan, dan persatuan sesama warga Indonesia . Tidak bersikap dan bertindak yang bersifat permusuhan terhadap anggota masyarakat lain. Mengembangkan rasa persaudaraan dan kekeluargaan diantara sesama anggota masyarakat. Mengembangakan persatuan Indonesia yang ber-Bhineka Tunggal lka. Tidak membeda-bedakan perlakuan (diskriminasi) terhadap anggota masyarakat. Bangga sebagai Bangsa Indonesia dan ber-Tanah Air Indonesia. Secara spesifik, tujuan nya adalah agar kita sebagai warga Negara Indonesia harus bisa 
menjaga kelestarian nilai-nilai Pancasila demi terjaganya kehidupan dan tatanan kehidupan sebagai warga Negara Indonesia yang baik. Sehingga akan terlihat lebih baik lagi citra nama baik bangsa di mata dunia. Dan dapat memperkuat Pancasila sebagai dasar falsafah Negara dan ideologi bangsa melalui revitalisasi nilai-nilai dasar Pancasila sebagai norma dasar kehidupan bermasyarakat,berbangsa,dan bernegara. Dapat mempersiapkan sikap mental agar mampu menganalisis dan mencari solusi terhadap berbagai persoalan kehidupan bermasyarakat, berbangsa, dan bernegara melalui system pemikiran yang berdasarkan nilai-nilai Pancasila dan UUD Negara RI Tahun 1945. Membentuk sikap mental yang mampu mengapreasisasi nilai-nilai ketuhanan, kemanusiaan, kecintaan pada tanah air, dan kesatuan bangsa, serta penguatan masyarakat madani yang demokratis, berkeadilan, dan bermartabat berlandaskan Pancasila, untuk mampu berinteraksi dengan dinamika dan eksternal masyarakat bangsa Indonesia (Direktorat Pembelajaraan dan Kemahasiswaan, 2013: Viii).

Menunjukan pergaulan bangsa demi persatuan dan kesatuan bangsa yang berBhineka Tunggal Ika. Nilai-nilai etis persatuan dan kesatuan harus mengakar kuat dalam lingkungan pergaulan kebangsaan yang lebih dekat sebelum menjangkau pergaulan dunia yang lebih jauh. Indonesia memiliki prinsip dan visi kebangsaan yang kuat, bukan saja dapat mempertemukan kemajemukan masyarakat dalam kebaruan komunitas politik bersama, melainkan juga mampu memberi kemungkinan bagi keragaman komunitas untuk tidak tercerabut dari akar tradisi dan kesejarahan masing-masing, dalam khasanah Indonesia, hal tersebut menyerupai perspektif "etnosimbolis" yang memadukan antara prespektif "modernis" yang menekankan unsur-unsur kebaruan dalam kebangsaan dengan perspektif "primordialis" dan "penenialis" yang melihat unsur lama dalam kebangsaan.

Pembudayaan nilai-nilai Pancasila, yaitu proses pembudayaan pada domein value (nilai). Realitas nilai adalah merupakan sesuatu yang hanya dapat dipahami dan dimenegrti oleh manusai. Oleh karena itu dalam proses pembudayaan harus menggunakan strategi dengan senangtiasa menghubungkan nilai-nilai Pancasila dengan realitas kongkrit kehidupan manusia. Misalnya nilai-nilai kemanusiaan sila kedua Pancasila adalah, selain pengertian kemanusiaan juga harus dihubungkan dengan nilainilai Pancasila lainnya, dengan realita yang kongkrit dalam kehidupan manusia. Contoh sikap toleransi dalam sila kedua Pancasila menanamkan penegrtian nilai kemanusian dengan melalukan kegiatan kemanusiaan, mengangkat harkat dan martabat manusia. Serta memberikan nilai penegrtian kemanusiaan dengan kehidupan praktisi misalnya, memberikan nilai kerakyatan misalnya nilai kemanusiaan yang juga dihubungkan dengan nilai kehidupan sehari-hari dengan melakukan kegiatan kemanusiaan, cinta tanah air, bangsa dan Negara, cinta terhadap produk dalam nengeri, tidak membedakan suku rasa tau etnis. Memberikan hak yang sama pada orang lain, menghargai pendapat orang lain, musyawarah untuk mufakat dalam suatu masalah dalam kehidupan bermasyarakat. Memenuhi kewajiban dalam kehidupan bermasyarakat dan mewujudkan kebersamaan dengan tidak menonjolkan kepentingan individu, dan lain sebagainya.

Proses pembudayaan nilai-nilai Pancasila dapat dilakukan dengan berbagai metode, namun yang terpenting sesuai dengan tingkat pengetahuan kelompok masyarakat yang menjadi objek pembudaya. Pembudayaan Pancasila pada sila ke dua Pancasila dalam kehidupan social, yaitu proses dan pemudayaan pancasila dalam kehidupan social-budaya secara kongkrit, dalam hubungan ini realita Pancasila dilakukan secara langsung dalam kehidupan masyarakat. Nilai-nilai Pancasila diaktualisasikan dalam kehidupan masyarakat, sesuai dengan situasi, kondisi dan keadaaan masyarakat. Misalnya dalam lingkungan RT, RW yang dengan langsung mempraktekkan dan mewujudkan nilai-nilai Pancasila. Misalnya praktek-realisasi musyawarah-mufakat, sikap toleransi, sikap tenggang rasa, realisasi kemanusiaan, misalnya membantu warga yang sedang kesulitan dan lain sebagainya. Dewasa ini 
kehidupan masyarakat semakin komplek dan semakin janggih, oleh karena itu pembudayaan nilai pada kehidupan social dapat juga dilakukan melalui IT, Internet, Facebook ( Yang sering diistilahkan dengan masyarakat dunia maya) Misalnya dengan membentuk komunitas tertentu, berkomunikasi dengan menggunakan media online, dan dengan sendirinya pesan-pesan komunikasi dirumuskan dengan berdasarkan nilai-nilai Pancasila, hal ini sangat efektif tercantum untuk kalangan generasi muda Sukanto dalam (Kaelan, 2014: 19).

Pembudayaan Pancasila dalam wujud Budaya Fisik, yaitu pembudayaan nilainilai Pancasila secara langsung dalam wujud kebudayaan fisik, dengan gambar symbol nasionalisme, semboyan kebangsaandan lain sebagainya. Dapat pula dalam suatuvcidera mata, yang didalamnya terkandung, atau icon Pancasila. Secara luas dapat dilakukan pada benda budaya ini seperti buku-buku cerita anak, gantungan kunci, patung, pakaian, lukisan dan lain sebagainya.

Negara pada hakekatnya menurut pandangan filsafat Pancasila adalah merupakan suatu persekutuan hidup manusia, yang merupakan suatu penjelmaan sifat kodrat manusia sebagai mahluk individu dan mahluk social serta manusia Tuhan Yang Maha Esa. Negara adalah lembaga kemanusiaa, lembaga kemasyrakatan yang bertujuan demi tercapainya harkat dan martabat serta kesejahteraan lahir dan bathin, sehingga tidak mengherankan jikalau manusia adalah merupakan subjek pendukung pokok Negara. Oleh karena itu Negara adalah suatu Negara Kebangsaan yang Berketuhanan Yang Maha ESa, dan Berkemanusiaan yang Adil dan Beradab.

Konsekwensinya segala aspek dalam pelenyenggaraan Negara, asas kerohanian, struktur dan keadaan Negara harus koheren dengan hakikat manusia yang adil dan beradab. Struktur dan keadaan Negara tersebut adalah meliputi (1) bentuk Negara (2) tujuan Negara (3) organisasi Negara (4) kekuasaan Negara, (5)penguasa Negara (6) warga Negara, masyarakat, rakyat dan bangsa (Notonegoro, 1975 dalam Kemendikbud) Negara dalam pengertian ini menempatkan manusia sebagai dasar ontologis, sehingga manusia adalah sebagai asal mulanegara dan kekuasaaan Negara. Manusia adalah merupakan paradigma sentral dalam setiap aspek penyenggaraan negar, terutama dalam pembangunnan Negara (Pembangunan Nasional).

Sebagai Negara yang kemanusiaan, maka Negara"....melindungi seluruh warganya serta seluruh tumpah darahnya." Hal ini berarti Negara melindungi seluruh manusia sebagai warganya tidak terkecuali. Oleh karena itu Negara harus melindungi hak-hak azasi manusia, serta mewujudkannya. Dalam suatu system peraturan perundang-undangan Negara. Hal ini sebagaimana termuat dalam UUD 1945 pasal $27,28,29,30,31$. Negara berkewajiban mengembangkan harkat dan martabat manusia, bahkan Negara harus menempatkan moral kemanusiaan sebagai moral Negara dan pelenyenggara pemerintah Negara (Kemendikbud, 2000: 102).

Negara Pancasila sebagai negara Kebangsaan yang ber kemanusiaan yang Adil dan Beradab, mendasarkan nasionalisme (kebangsaan) berdasarkan hakikat kodrat manusia yang adil dan beradab. Kebangsaan Indonesia adalah kebangsaan yang berkemanusiaaan yang Chauvinistic.

Kebangsaan Indonesia yang berdasarkan Pancasaila mengakui dan mendasarkan kebangsaan dan berkemanusiaan. Hal ini berarti bagi bangsa Indonesiamengakui jiwa bangsa adalah sebagai penjelmaan kodrat manusia sebagai mahluk individu dan mahluk social, oleh karena itu bangsa Indonesia adalah sebagai bagian dari umat manusia. Maka dalam pergaulan antar bangsa, antar manusia dalam tata dunia internasional bangsa Indonesia mengembangkan suatu pergaulan internasional berdasarkan atas kodrat manusia, serta mengakui kemerdekaan bangsa sebagai hak yang dimiliki oleh hakikat manusia sebagai individu dan mahluk social. Oleh karena itu penjajahan atas bangsa adalah pelanggaran atas hak kodrat manusia sebagai bangsa dan individu, dan tidak sesuai dengan peri keadilan serta keadaban manusia. 


\section{B. Implementasi Nilai Kedua Dari Pancasila Pada Pembelajaran Di Program Studi Pendidikan Sejarah.}

Observasi pertama yaitu pada tanggal 28 September 2020 dalam pembelajaran dengan motede daring dosen pancasila memberikan materi sesuai silabus "Pancasila dalam konteks sejarah perjuangan bangsa Indonesia".

Pertama dosen melakukan pembukaan dengan mengucapkan salam dilanjutkan dengan mengabsen. Setelah itu dosen mengulas kembali materi minggu lalu selama tiga menit dan dilanjutkan dengan materi baru yaitu Pancasila dalam konteks sejarah perjuangan bangsa Indonesia.

Pancasila dalam konteks sejarah perjuangan bangsa yang pertama dimulai zaman kerajaan. Yang menjadi ikon kerajaan pada saat itu adalah zaman kerajaan Kutai, Sriwijaya dan Majapahit. Yang patut dicontoh dari ketiga kerajaan tersebut sudah berseloka Bineka Tunggal Ika yang sekaligus terkandung nilai-nilai religius, jati diri bangsa, kepribadian, adat istiadat dan kebudayaan. Konteks nilai pancasila dari sila ke dua Pancasila saat itu bias dipahami, dibentuk dalam nilai kemanusiaan yang bersifat universal dari hukum Tuhan atau hukum alam dan sifat-sifat social yang bersifat horizontal yang dianggap penting sebagai pundamental etika atau norma dalam kehidupan bermasyarakat dan bernegara dalam pergaulan dunia.

Prinsip kebangsaan yang luas mengarah pada persaudaraan dunia yang dikembangkan melalui jalur eksternalisasi dan internalisasi. Nilai-nilai etis kemanusiaan harus dapat mengakar kuat dalam lingkungan pergaulan bangsa yang lebih dekat dalam menjangkau pergaulan nasional. Bangsa Indonesia memiliki prinsip dan visi rasa kebangsaan yang kuat, kemajemukan masyarakat dalam komunitas bersama mampu memberikan hasanah ke Indonesiaan dengan melihat unsur kebangsaan di dalamnya. Sila kedua yaitu Kemanusiaan yang adil dan beradab memberikan dasar-dasar moralitas bahwa manusia dengan cara-cara yang beradab harus berdasarkan pada hakekat dan tujuan demi kesejahteraan, bukan untuk kesombongan, kecongkakan dan keserakahan, tetapi demi untuk meningkatkan harkat, martabat yang baik. Intinya yang dapat di ambil dari ketiga kerajaan tersebut, sebagai ikon dalam nilai-nilai pancasila bahwa seperangkat hak dan keberadaan manusia sebagai mahluk Tuhan Yang Maha Esa dan merupakan anugerahnya, wajib di hormati, di junjung tingggi oleh pribadinya.

Pada tahap elaborasi dosen memberikan tugas pada mahasiswa berupa makalah mengenai nilai sila ke dua Pancasila Kemanusiaan Yang Adil Dan Beradab dan dikumpulkan pada pertemuan selanjutnya.

\section{SIMPULAN}

Nilai Pancasila sila ke dua Kemanusiaan yang Adil dan Beradab bahwa Semua rakyat Indonesia memiliki hak yang sama di mata hulum, agama, masyarakat dan lainnya, tidak ada perbedaan antara ras satu dengan yang lainnya antar sesame rakyat Indonesia, sikap menghormati antar umat beragama, tidak memaksakan kehendak antar umat beragama, tidak mencemooh atau mengejek kepercayaan orang lain.

Zaman kerajaan Kutai, Sriwijaya dan Majapahit. Yang patut dicontoh dari ketiga kerajaan tersebut sudah berseloka Bineka Tunggal lka yang sekaligus terkandung nilai-nilai religius, jati diri bangsa, kepribadian, adat istiadat dan kebudayaan. Konteks nilai pancasila dari sila ke dua Pancasila saat itu bias dipahami, dibentuk dalam nilai kemanusiaan yang bersifat universal dari hukum Tuhan atau hukum alam dan sifat-sifat social yang bersifat horizontal yang dianggap penting sebagai pundamental etika atau norma dalam kehidupan bermasyarakat dan bernegara dalam pergaulan dunia.

\section{DAFTAR PUSTAKA}

Kemendikbud, 2000. Pendidikan Pancasila. Jakarta. Dikbud Kaelan, 2014. Pendidikan Pancasila. Yogyakarta. Paradigma 
SHEs: Conference Series 3 (2) (2020) 77 - 85

Direktorat Pembelajaraan dan Kemahasiswaan, 2013. Nilai Pancasila. Jakarta Subakti, 2010. Nilai-nilai

Paradigma Sejarah. Skripsi

https://saintif.com/com/nilai-nilai 